\title{
Incident Pneumonia and Mortality in Patients with Chronic Obstructive Pulmonary Disease
}

\section{A Double Effect of Inhaled Corticosteroids?}

\author{
Emir Festic ${ }^{1}$ and Paul D. Scanlon ${ }^{2}$ \\ ${ }^{1}$ Pulmonary and Critical Care Medicine, Mayo Clinic, Jacksonville, Florida; and ${ }^{2}$ Pulmonary and Critical Care Medicine, Mayo Clinic, \\ Rochester, Minnesota
}

\begin{abstract}
Inhaled corticosteroids are commonly prescribed for patients with severe chronic obstructive pulmonary disease. Although their use improves quality of life and reduces exacerbations, it is associated with increased risk of pneumonia. Curiously, their use has not been associated with increased risk of pneumonia-related or overall mortality. We review pertinent literature to further explore the effects of inhaled corticosteroids on incident pneumonia and mortality in patients with chronic obstructive pulmonary disease. The association of use of inhaled corticosteroids and incident pneumonia is substantial and has been present in the majority of the studies on the topic. This includes both randomized controlled trials and observational studies. However, all of the studies have substantial risk of bias. Most randomized trials are limited by lack of systematic ascertainment of pneumonia; they depended on
\end{abstract}

adverse event reporting. Many observational studies included proper radiographic assessment of pneumonia, but they are limited by their retrospective, observational design. The unadjusted higher risk of pneumonia is associated with longer duration of use, more potent ICS compounds, and higher doses. That implies a dose-effect relationship. Unlike pneumonia, mortality is a precise outcome. Despite the robust association of inhaled corticosteroid use with increased risk of pneumonia, all studies find either no difference or a reduction in pulmonary-related and overall mortality associated with the use of inhaled corticosteroids. These observations suggest a double effect of inhaled corticosteroids (i.e., an adverse effect plus an unexplained mitigating effect).

Keywords: pneumonia; mortality; corticosteroids; chronic obstructive pulmonary disease
Inhaled corticosteroids (ICS) are antiinflammatory medications that have been shown to improve symptoms and health status and reduce the incidence of exacerbations in patients with chronic obstructive pulmonary disease (COPD). They are recommended for use by patients with severe COPD or frequent exacerbations (1). Since Toward a Revolution in COPD Health (TORCH) investigators reported increased incidence of pneumonia among patients using ICS in 2007 (2), several well-designed randomized controlled trials (RCTs) have demonstrated a similar risk (3-7). Although these trials relied on unadjusted adverse event reports of pneumonia, frequently without systematic ascertainment or radiographic confirmation, the bulk of evidence supports increased risk of pneumonia associated with use of ICS. We recently demonstrated that this risk is slightly attenuated but not eliminated by adjusting for demographic characteristics, comorbidities, and concurrent medications (8). Other risk factors included higher potency of the ICS compounds, higher doses, and longer duration of use (9), which suggests a dose-effect relationship. The risk is also increased for elderly patients with more severe COPD (10).

Several recent observational studies reported either similar or lesser mortality among ICS users, despite increased risk of pneumonia (11-13). Some of these studies also reported an improvement in other

(Received in original form September 24, 2014; accepted in final form November 17, 2014)

Supported in part by NIH grant UL1 TR000135 and the Mayo Clinic Foundation (E.F.).

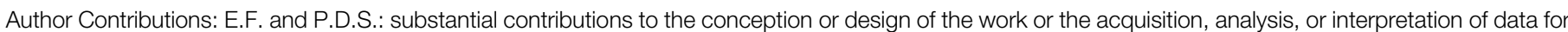
the work; drafting the work or revising it critically for important intellectual content; final approval of the version to be published; and agreement to be

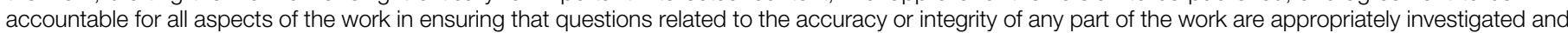
resolved.

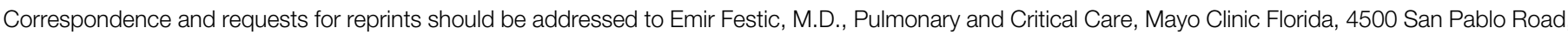
Jacksonville, FL 32082. E-mail: festic.emir@mayo.edu

Am J Respir Crit Care Med Vol 191, Iss 2, pp 141-148, Jan 15, 2015

Copyright (C) 2015 by the American Thoracic Society

Originally Published in Press as DOI: 10.1164/rccm.201409-1654PP on November 19, 2014

Internet address: www.atsjournals.org 
pertinent outcomes among patients using ICS, such as decreased risk of parapneumonic effusion and less frequent need for mechanical ventilation and vasopressors $(10,11,14)$. Pneumonia ascertainment was better and more systematic in these observational studies than in the RCTs analyzed in a previous systematic review (15). The recent observational studies mostly focused on more severe pneumonia, requiring hospitalization, whereas the RCTs were performed in the outpatient setting and included a large proportion of pneumonias occurring among ambulatory patients. A much larger number of pneumonia events have been reported and analyzed in studies with observational design.

Even casual reading of the literature raises the possibility of a disconnect between reports of increased risk of pneumonia with ICS use and yet similar or improved mortality outcomes. Consequently, we performed comprehensive review of all studies on the topic to clarify this. We included RCTs and observational studies of patients with COPD using inhaled corticosteroid medications published since the late 1990s, when the first trials of inhaled fluticasone (16) and budesonide $(17,18)$ reported incident pneumonia events.

\section{Pneumonia}

In all identified RCTs, pneumonia was measured as a safety or adverse effect (Table 1). These trials studied more than 30,000 patients, more than half of whom were assigned to use ICS. All randomized trials were done with outpatient COPD populations. The majority of RCTs reported increased risk of pneumonia. The most studied medication has been fluticasone, followed by budesonide and mometasone. TORCH was the largest RCT; it included more than 6,000 patients and was the first trial to show significantly increased risk of pneumonia (hazard ratio [HR], 1.64; 95\% confidence interval [CI], 1.33-2.02) (19). Several other trials demonstrated increased risk of pneumonia among ICS users $(3-7,17,20,21)$, with HRs from $\sim 1.90$ (95\% CI, 1.04-3.49) (3) to 3.09 (95\% CI, 1.34-7.12) (20). Some trials showed risk to be increased, but not significantly so, because CIs included relative risk of 1 . No RCT showed significantly decreased risk of pneumonia, although in two trials $(18,22)$ the estimated risks were in the protective range but with CI crossing relative risk of 1 . Vestbo and colleagues investigated long-term effects of inhaled budesonide in mild and moderate COPD. The relative risk of pneumonia was 0.67 (95\% CI, 0.37-1.20) (18). A decade later, Rennard and colleagues investigated efficacy and tolerability of budesonide/ formoterol in patients with COPD, and the relative risk was 0.74 (95\% CI, 0.47-1.18) (22). Of note, both studies investigated budesonide, which is associated with less risk of pneumonia compared with fluticasone in other studies (23-25). This could be related to the difference between fluticasone and budesonide in potency or clearance rates from airways $(26,27)$.

Observational studies included more systematic assessment for pneumonia, including radiographic confirmation (Table 2). They assessed more than 250,000 patients, approximately 50,000 of whom used ICS, for risk of pneumonia requiring an emergency room evaluation or hospital admission. All observational studies showed increased risk of pneumonia, with HRs ranging from 1.10 (95\% CI, 1.08-1.13) (11) to 2.65 (95\% CI, 1.25-5.61) (28).

\section{Pneumonia-related Mortality}

Five RCTs of ICS in COPD have reported unadjusted risk of pneumonia-related mortality; none found a difference between ICS and non-ICS arms $(5-7,19,20)$. The TORCH trial had the largest number of participants and hence the greatest weight in estimating the risk (19). Four other trials had wide CIs; thus, there is a lack of precision in estimating pneumonia-related mortality from RCTs. Indeed, it is often impossible to determine whether a patient dies due to pneumonia or merely with pneumonia. For the purpose of this review, we considered short-term (30-d) mortality after hospitalization for pneumonia as pneumonia-related mortality in observational studies.

We identified seven observational studies of ICS in patients with COPD that evaluated pneumonia-related mortality after hospitalization for pneumonia. Three studies included more than three-fourths of all patients. They showed decreased 30-day mortality on hospitalization for pneumonia using national administrative databases
(11, 12, 29). A study of Veterans Affairs (VA) hospitals assessed the association of ICS exposure with mortality for more than 6,000 hospitalized subjects with COPD with pneumonia in a covariate-adjusted regression model (12). The unadjusted relative risk was 0.50 (95\% CI, 0.41-0.60) for 30-day mortality. Joo and colleagues analyzed a dataset of more than 14,000 patients from the VA and Centers for Medicare and Medicaid Services, and the results showed decreased risk of 30-day mortality followed admission for pneumonia (odds ratio [OR], 0.74 [95\% CI, 0.66-0.83]) (29). More recently, Chen and colleagues reported outcomes of more than 15,000 patients with COPD with pneumonia through the use of the VA database (11). The short-term mortality after hospitalization for pneumonia was again decreased (relative risk, 0.75 [95\% CI, 0.69-0.82]). Four other studies, encompassing only one-fourth of patients, demonstrated no increased risk of pneumonia-related death with the wide CIs $(8,13,14,30)$. Retrospective, observational design adds to the above-mentioned imprecision of assessment of pneumoniarelated mortality. However, it is evident that the decreased short-term mortality after hospitalization for pneumonia is in the direction opposite to the increased risk of pneumonia in the same studies. Although Ernst and colleagues in restricted subgroup analysis reported that more patients with COPD hospitalized with pneumonia who died within 30 days used ICS than not, this subgroup of patients was confounded by more severe respiratory disease, greater frequency of COPD hospitalization, and thus the greater number of prescriptions for all respiratory drugs, including systemic corticosteroids and antibiotics (9). Analysis of all patients in this cohort showed lower all-cause 30-day mortality among patients hospitalized for pneumonia who were dispensed versus those not dispensed ICS (7.4 vs. $8.2 \%, P=0.05$ ).

\section{Overall Mortality}

We reviewed all published RCTs to estimate unadjusted risk of overall or long-term (90-d) mortality with ICS use in patients with COPD. In all studies but one, the risk was not different from the comparison arm. The only study that showed significant 
Table 1. Reviewed Randomized Controlled Trials

Study Interventions

Aaron et al. (41)

Anzueto et al. (4)

Burge et al. (42)

Calverley et al. (43)

Calverley et al. (44)

Calverley et al. (45)

Calverley et al. (5)

Crim et al. (19)

Doherty et al. (46)

Dransfield et al. (7)

Ferguson et al. (3)

Kardos et al. (20)

Kerwin et al. (47)

Mahler et al. (48)

Martinez et al. (49)

Pauwels et al. (17)

Rennard et al. (22)
Tiotropium $18 \mu \mathrm{g}+$ placebo

Tiotropium $18 \mu \mathrm{g}+$ salmeterol $25 \mu \mathrm{g}$

Tiotropium $18 \mu \mathrm{g}$ + fluticasone/salmeterol $250 / 25 \mu \mathrm{g}$

Fluticasone propionate/salmeterol 250/50 $\mu \mathrm{g}$

Salmeterol $50 \mu \mathrm{g}$

Fluticasone propionate $500 \mu \mathrm{g}$

Placebo

Budesonide/formoterol 320/9 $\mu \mathrm{g}$

Budesonide $400 \mu \mathrm{g}$

Formoterol $9 \mu \mathrm{g}$

Placebo

Fluticasone/salmeterol 500/50 $\mu \mathrm{g}$

Fluticasone propionate $500 \mu \mathrm{g}$

Salmeterol $50 \mu \mathrm{g}$

Placebo

Beclomethasone/formoterol MDI 100/6 $\mu \mathrm{g}$

Budesonide/formoterol DPI 200/6 $\mu \mathrm{g}$

Formoterol DPI $12 \mu \mathrm{g}$

Salmeterol/fluticasone propionate $50 / 500 \mu \mathrm{g}$

Tiotropium bromide $18 \mu \mathrm{g}$

Fluticasone $500 \mu \mathrm{g}$

Salmeterol $50 \mu \mathrm{g}$

Salmeterol/fluticasone 50/500 $\mu \mathrm{g}$

Placebo

Mometasone/formoterol 400/10 $\mu \mathrm{g}$

Mometasone/formoterol 200/10 $\mu \mathrm{g}$

Mometasone $400 \mu \mathrm{g}$

Formoterol $10 \mu \mathrm{g}$

Placebo

Vilanterol $25 \mu \mathrm{g}$

Fluticasone furoate $50 \mu \mathrm{g}$ + vilanterol $25 \mu \mathrm{g}$

Fluticasone furoate $100+$ vilanterol $25 \mu \mathrm{g}$

Fluticasone $200 \mu \mathrm{g}$ + vilanterol $25 \mu \mathrm{g}$

Fluticasone propionate/salmeterol $250 / 50 \mu \mathrm{g}$

Salmeterol $50 \mu \mathrm{g}$

Fluticasone propionate/salmeterol 500/50 $\mu \mathrm{g}$

Salmeterol $50 \mu \mathrm{g}$

Fluticasone/vilanterol 100/25 $\mu \mathrm{g}$

Fluticasone/vilanterol $50 / 25 \mu \mathrm{g}$

Fluticasone $100 \mu \mathrm{g}$

Vilanterol $25 \mu \mathrm{g}$

Placebo

Fluticasone $500 \mu \mathrm{g}$

Salmeterol $50 \mu \mathrm{g}$

Fluticasone/salmeterol 500/50 $\mu \mathrm{g}$

Placebo

Fluticasone furoate $100 \mu \mathrm{g}$

Fluticasone furoate $200 \mu \mathrm{g}$

Vilanterol $25 \mu \mathrm{g}$

Fluticasone furoate/vilanterol 100/25 $\mu \mathrm{g}$

Fluticasone furoate/vilanterol 200/25 $\mu \mathrm{g}$

Placebo

Fluticasone propionate $500 \mu \mathrm{g}$

Placebo

Budesonide $400 \mu \mathrm{g}$

Placebo

Budesonide/formoterol pMDI 320/9 $\mu \mathrm{g}$

Budesonide/formoterol pMDI 160/9 $\mu \mathrm{g}$

Formoterol DPI $9 \mu \mathrm{g}$

Placebo
Pneumonia

Overall mortality

148

145

394

403

376

375

254

257

255

256

358

374

372

361

237

242

239

658

665

1,534

1,521

1,533

1,524

225

239

253

243

236

409

408

403

402

394

388

507

487

206

206

206

205

207

168

160

165

181

204

203

203

204

205

205

142

139

634

643

494

494

495

481
Pneumonia

Overall mortality

Pneumonia

Overall mortality

Pneumonia

Pneumonia

Pneumonia

Overall mortality

Pneumonia

Pneumonia mortality

Overall mortality

Pneumonia

Pneumonia mortality

Overall mortality

Pneumonia

Overall mortality

Pneumonia

Pneumonia mortality

Overall mortality

Pneumonia

Overall mortality

Pneumonia

Pneumonia mortality

Overall mortality

Pneumonia

Overall mortality

Pneumonia

Pneumonia mortality

Overall mortality

Pneumonia

Overall mortality

Pneumonia

Overall mortality

Pneumonia

Overall mortality

Pneumonia

Overall mortalit 
Table 1. (Continued)

\begin{tabular}{|c|c|c|c|}
\hline Study & Interventions & Patients Enrolled & Estimable Outcomes \\
\hline \multirow[t]{3}{*}{ Sharafkhaneh et al. (6) } & Budesonide/formoterol pMDI 320/9 $\mu \mathrm{g}$ & 407 & Pneumonia \\
\hline & Budesonide/formoterol pMDI 160/9 $\mu \mathrm{g}$ & 408 & Pneumonia mortality \\
\hline & Formoterol DPI $9 \mu \mathrm{g}$ & 404 & Overall mortality \\
\hline \multirow{3}{*}{ Szafranski et al. (50) } & Budesonide/formoterol 320/9 $\mu \mathrm{g}$ & 208 & Pneumonia \\
\hline & Budesonide $200 \mu \mathrm{g}$ & 198 & Overall mortality \\
\hline & $\begin{array}{l}\text { Formoterol } 4.5 \mu \mathrm{g} \\
\text { Placebo }\end{array}$ & $\begin{array}{l}201 \\
205\end{array}$ & \\
\hline \multirow[t]{6}{*}{ Tashkin et al. (51) } & Budesonide/formoterol pMDI 320/9 $\mu \mathrm{g}$ & 277 & Pneumonia \\
\hline & Budesonide/formoterol pMDI $160 / 9 \mu \mathrm{g}$ & 281 & Overall mortality \\
\hline & $\begin{array}{l}\text { Budesonide pMDI } 320 \mu \mathrm{g}+\text { formoterol } \\
\text { DPI } 9 \mu \mathrm{g}\end{array}$ & 287 & \\
\hline & Budesonide pMDI $320 \mu \mathrm{g}$ & 275 & \\
\hline & Formoterol DPI $9 \mu \mathrm{g}$ & 284 & \\
\hline & Placebo & 300 & \\
\hline \multirow[t]{5}{*}{ Tashkin et al. (52) } & Mometasone/formoterol $400 / 10 \mu \mathrm{g}$ & 217 & Pneumonia \\
\hline & Mometasone/formoterol $200 / 10 \mu \mathrm{g}$ & 207 & Overall mortality \\
\hline & Mometasone $400 \mu \mathrm{g}$ & 210 & \\
\hline & Formoterol $10 \mu \mathrm{g}$ & 209 & \\
\hline & Placebo & 212 & \\
\hline \multirow[t]{2}{*}{ Van der valk et al. (53) } & Fluticasone $500 \mu \mathrm{g}$ & 123 & Pneumonia \\
\hline & Placebo & 121 & Overall Mortality \\
\hline \multirow[t]{2}{*}{ Vestbo et al. (54) } & Budesonide & 145 & Pneumonia \\
\hline & Placebo & 145 & Overall Mortality \\
\hline \multirow[t]{2}{*}{ Vogelmeier et al. (55) } & $\begin{array}{l}\text { QVA } 149 \text { (LABA indacaterol and the LAMA } \\
\text { glycopyrronium in fixed combination } \\
110 / 50 \mu \mathrm{g})\end{array}$ & 259 & Pneumonia \\
\hline & Salmeterol/fluticasone $50 \mu \mathrm{g} / 500 \mu \mathrm{g}$ & 264 & Overall mortality \\
\hline \multirow[t]{2}{*}{ Welte et al. (56) } & $\begin{array}{l}\text { Tiotropium } 18 \mu \mathrm{g}+\text { budesonide/formoterol } \\
320 / 9 \mu \mathrm{g}\end{array}$ & 329 & Pneumonia \\
\hline & Tiotropium $18 \mu \mathrm{g}+$ placebo & 331 & Overall mortality \\
\hline \multirow{2}{*}{ Wouters et al. (21) } & Salmeterol/fluticasone $50 \mu \mathrm{g} / 500 \mu \mathrm{g}$ & 189 & Pneumonia \\
\hline & Salmeterol $50 \mu \mathrm{g}$ & 184 & Overall mortality \\
\hline
\end{tabular}

Definition of abbreviations: $\mathrm{DPI}=$ dry powder inhaler; LABA = long-acting $\beta$-agonist; $L A M A=$ long-acting muscarinic agent; $M D I=$ metered dose inhaler; $\mathrm{pMDI}=$ pressurized metered dose inhaler.

difference in risk was reported by Calverley and colleagues, with the estimated relative risk in the protective range: 0.56 (95\% CI, $0.33-0.94)(5)$. This trial, Investigating New Standards for Prophylaxis in Reduction of Exacerbations (INSPIRE), was a 2 -year study of 1,323 patients randomized to salmeterol/fluticasone propionate twice daily versus once-daily tiotropium. It showed a twofold increase in the risk of pneumonia among patients using fluticasone. However, one-half of all pneumonia events in the fluticasone arm were associated with an ongoing or unresolved COPD exacerbation. The data interpretation from this study's daily record cards suggested identical numbers of $d e$ novo pneumonias in both ICS (fluticasone) and non-ICS arms but more unresolved exacerbations preceding pneumonia events in the patients treated with ICS (5).

Six observational studies estimated risk of overall mortality. In addition to two above-mentioned studies that showed lower risk of both short-term and longerterm mortality after hospitalization for pneumonia $(11,12)$, a case-control study by Ernst and colleagues showed a small decrease in risk of all-cause mortality (OR, 0.89; 95\% CI, 0.80-1.00) (9). This was despite more than twice the risk of pneumonia observed in this nested case-control study (OR, 2.14; 95\% CI, 2.02-2.28). These three studies encompassed $80 \%$ of all patients and showed significantly decreased all-cause or longer-term (90-d) mortality. Three other studies, including $20 \%$ of all reported patients, demonstrated no increased risk of overall mortality relative to ICS use $(8,13,30)$.

A very recently published observational population-based study from Ontario analyzed health administration data for patients with newly prescribed combination of ICS/long-acting $\beta$-agonists (LABA) compared with LABA alone within an 8 -year period (31). It showed no difference in incidence of pneumonia requiring hospitalization between the two arms after propensity-score-matched regression analysis (HR, 1.01; 95\% CI, 0.93-1.08). However, patients with new prescriptions for ICS/LABA compared with those using LABA alone had decreased risk of overall mortality (HR, 0.92; 95\% CI, 0.88-0.96). It is not known which ICS medications were predominantly used (budesonide vs. fluticasone) or in which doses. Unlike other studies on the topic, this study included patients with previous diagnosis of asthma. It is possible that inclusion of patients with asthma affected the estimated risk of incident pneumonia, as most previous studies demonstrated no increased risk of pneumonia in patients with asthma (32-34). An updated metaanalysis of observational studies including this one would be informative. 
Table 2. Reviewed Observational Studies

\begin{tabular}{lcl}
\hline Study & $\begin{array}{c}\text { ICS Patients; } \\
\text { Non-ICS Patients }\end{array}$ & Estimable Outcomes \\
Ernst et al. (9) & 12,$354 ; 83,413$ & $\begin{array}{l}\text { Pneumonia } \\
\text { Overall mortality } \\
\text { Pneumonia }\end{array}$ \\
Joo et al. (57) & 21,$054 ; 110,537$ & $\begin{array}{l}\text { Pneumonia mortality } \\
\text { Pneumonia }\end{array}$ \\
Chen et al. (11) & 8,$271 ; 7,497$ & $\begin{array}{l}\text { Pneumonia mortality } \\
\text { Overall mortality }\end{array}$ \\
Cheng et al. (28) & $125 ; 149$ & $\begin{array}{l}\text { Pneumonia } \\
\text { Pneumonia mortality } \\
\text { Pneumonia }\end{array}$ \\
Festic et al. (58) & $226 ; 363$ & $\begin{array}{l}\text { Pneumonia mortality } \\
\text { Overall mortality }\end{array}$ \\
Ko et al. (30) & & $\begin{array}{l}\text { Pneumonia mortality } \\
\text { Overall mortality } \\
\text { Pneumonia mortality } \\
\text { Overall mortality }\end{array}$ \\
Malo de Molina et al. (12) & $42 ; 36$ & $\begin{array}{l}\text { Pneumonia mortality } \\
\text { Overall mortality } \\
\text { Pneumonia mortality }\end{array}$ \\
Sellares et al. (14) & 2,$420 ; 3,933$ & Overall mortality \\
\hline Singanayagam et al. (13) & $340 ; 394$ & S
\end{tabular}

Definition of abbreviations: ICS = inhaled corticosteroids

\section{The Double Effect of Inhaled Corticosteroids?}

Our literature review affirms the increase in unadjusted risk of pneumonia among ICS users, as demonstrated by both RCTs and observational studies of patients with COPD. Despite this risk, pneumonia-related and overall mortality were not different in RCTs and were decreased in the majority of patients enrolled into observational studies.

The evidence for an unadjusted increase in risk of pneumonia among users of ICS is strong. The risk of incident pneumonia is not the same for all patients, varying with potency, dose, and duration of ICS use (9). We recently found that the unadjusted increase in risk of pneumonia is attenuated after adjusting for baseline characteristics, comorbidities, and concurrent medications (8). Therefore, host characteristics, as well as differences in medication properties, are important in determining the additional risk for pneumonia. However, regardless of the effect of confounding factors on the true risk of pneumonia, these same factors would affect the mortality outcomes as well.

The rationale for the increased risk of pneumonia among patients with COPD using ICS may include a combination of immunosuppressive effect plus the effect of obstruction of airways that are colonized with bacteria (35). It has been shown that ICS can achieve locally high concentrations in the lung (36) and that their potency was directly proportional with the increased risk of pneumonia (9). The established immunosuppressive effects could then decrease the innate ability to battle primary or secondary (postviral) bacterial infections resulting in pneumonia.

On the other hand, ICS are potent antiinflammatory medications. They have been shown to up-regulate production of antiinflammatory proteins and to inhibit the transcription of proinflammatory cytokines and chemokines (37). It is plausible that these antiinflammatory effects may reduce the severity of incident pneumonia and then explain the observed change in the risk direction between pneumonia and mortality. Previous observational studies suggested a protective effect of ICS for selected groups of patients. In a study of patients at risk for pulmonary toxicity from chemotherapy, inhaled fluticasone reduced the incidence of delayed pulmonary toxicity (38). In a retrospective cohort of patients from Olmsted County, Minnesota and a large multicenter prospective Lung Injury Prediction Score (LIPS) cohort of patients at risk for acute lung injury, the use of ICS was associated with decreased risk of acute lung injury for patients with pneumonia and those at risk of direct lung injury, respectively $(39,40)$.

In this review, we find no difference in pneumonia-related or overall mortality despite significantly increased unadjusted risk for pneumonia in RCTs. This may not be surprising, given that all RCTs evaluated outpatient populations, and a good proportion of pneumonias were likely not severe. Simply said, relatively few incident pneumonias were fatal, so perhaps this could alternatively explain why no difference was found in pneumonia-related or overall mortality in RCTs. On the contrary, observational studies enrolled only patients with COPD with pneumonia requiring emergency room evaluation and hospitalization. Both COPD and pneumonia are among the most frequent causes of death, and as such the overall mortality might be expected to be increased in a group of patients with higher rates of serious pneumonia. However, our review suggests that the majority of these patients using ICS had actually decreased mortality risk. It is possible that if ICS were to possess protective effects, these would have been observed mostly in the cases of severe or potentially fatal pneumonia. Although observational studies typically have greater risk of bias compared with RCTs, there are several factors to be considered. The majority of RCTs reported have high risk of bias in ascertainment of pneumonia because of lack of radiographic confirmation of suspected pneumonia and low incidence of pneumonia events. On the contrary, the majority of observational studies included in our review systematically tracked and abstracted pneumonia events and used radiographic confirmation. Observational design allowed for including a much larger number of patients and assessing much larger number of pneumonia events. Finally, despite all the inherent limitations, both RCTs and observational studies showed remarkably similarly increased risk estimates for pneumonia, while paradoxically showing equivalent or lower pneumonia-related and overall mortality associated with use of ICS in COPD. These observations support a double effect of ICS: ICS predispose patients with COPD to the increased risk of pneumonia but conversely have a counterbalancing beneficial effect on mortality resulting in no net change, or possibly a slight improvement in mortality. In the absence of mechanistics trials, we can 
only postulate that either ICS decrease the severity of incident pneumonia or there is another mitigating effect of ICS that reduces total risk of death to counterbalance mortality associated with increased risk of pneumonia.

There are other noteworthy limitations of the studies we reviewed. Although the risks of outcomes we considered were mostly unadjusted, the large number of patients included in the studies partially alleviates this concern. Some studies used multivariate adjustments; however, the differing methodology and covariates used in the adjustment analyses preclude the accurate synthesis and interpretation of the adjusted results. Other confounding factors, particularly COPD severity and presence of comorbidities, would need to be addressed prospectively. We considered all patients on ICS as ICS users, regardless of adherence or whether ICS were used alone or in combination with other agents. Similarly, subjects who did not use ICS were all those not using ICS regardless of use of other agents. Our main intention was to assess for the possible double effect of ICS, and further analyses of ICS alone or in combination were not practical at this stage. Only future prospective trials of ICS, which would systematically assess and monitor pneumonia as a prespecified outcome using objective pneumonia definitions, could clarify this and other abovementioned concerns.

Author disclosures are available with the text of this article at www.atsjournals.org.

\section{References}

1. Global Initiative for Chronic Obstructive Lung Disease. Global strategy for the diagnosis, management and prevention of COPD [updated 2014 Jan; accessed 2014 Mar 17]. Available from: http://www. goldcopd.org/

2. Calverley PM, Anderson JA, Celli B, Ferguson GT, Jenkins C, Jones PW, Yates BS, Vestbo J, TORCH Investigators. Salmeterol and fluticasone propionate and survival in chronic obstructive pulmonary disease. N Engl J Med 2007;356:775-89.

3. Ferguson GT, Anzueto A, Fei R, Emmett A, Knobil K, Kalberg C. Effect of fluticasone propionate/salmeterol (250/50 mug) or salmeterol (50 mug) on COPD exacerbations. Respir Med 2008;102:1099-1108.

4. Anzueto A, Ferguson GT, Feldman G, Chinsky K, Seibert A, Emmett A, Knobil K, O'Dell D, Kalberg C, Crater G. Effect of fluticasone propionate/salmeterol (250/50) on COPD exacerbations and impact on patient outcomes. COPD 2009;6:320-329.

5. Calverley PM, Stockley RA, Seemungal TA, Hagan G, Willits LR, Riley $\mathrm{JH}$, Wedzicha JA; Investigating New Standards for Prophylaxis in Reduction of Exacerbations (INSPIRE) Investigators. Reported pneumonia in patients with COPD: findings from the INSPIRE study. Chest 2011;139:505-512.

6. Sharafkhaneh A, Southard JG, Goldman M, Uryniak T, Martin UJ. Effect of budesonide/formoterol pMDI on COPD exacerbations: a doubleblind, randomized study. Respir Med 2012;106:257-268.

7. Dransfield MT, Bourbeau J, Jones PW, Hanania NA, Mahler DA, Vestbo J, Wachtel A, Martinez FJ, Barnhart F, Sanford L, et al. Once-daily inhaled fluticasone furoate and vilanterol versus vilanterol only for prevention of exacerbations of COPD: two replicate double-blind, parallel-group, randomised controlled trials. Lancet Respir Med 2013; 1:210-223.

8. Festic E, Bansal V, Gajic O, Lee AS; United States Critical Illness and Injury Trials Group: Lung Injury Prevention Study (USCIITG-LIPS) Investigators. Prehospital use of inhaled corticosteroids and point prevalence of pneumonia at the time of hospital admission: secondary analysis of a multicenter cohort study. Mayo Clin Proc 2014;89: 154-162.

9. Ernst P, Gonzalez AV, Brassard P, Suissa S. Inhaled corticosteroid use in chronic obstructive pulmonary disease and the risk of hospitalization for pneumonia. Am J Respir Crit Care Med 2007;176:162-166.

10. Liapikou A, Polverino E, Ewig S, Cillóniz C, Marcos MA, Mensa J, Bello S, Martin-Loeches I, Menéndez R, Torres A. Severity and outcomes of hospitalised community-acquired pneumonia in COPD patients. Eur Respir J 2012;39:855-861.

11. Chen D, Restrepo MI, Fine MJ, Pugh MJ, Anzueto A, Metersky ML, Nakashima B, Good C, Mortensen EM. Observational study of inhaled corticosteroids on outcomes for COPD patients with pneumonia. Am J Respir Crit Care Med 2011;184:312-316.

12. Malo de Molina R, Mortensen EM, Restrepo MI, Copeland LA, Pugh MJV, Anzueto A. Inhaled corticosteroid use is associated with lower mortality for subjects with COPD and hospitalised with pneumonia. Eur Respir J 2010;36:751-757.
13. Singanayagam A, Chalmers JD, Akram AR, Hill AT. Impact of inhaled corticosteroid use on outcome in COPD patients admitted with pneumonia. Eur Respir J 2011;38:36-41.

14. Sellares J, López-Giraldo A, Lucena C, Cilloniz C, Amaro R, Polverino E, Ferrer M, Menéndez R, Mensa J, Torres A. Influence of previous use of inhaled corticoids on the development of pleural effusion in community-acquired pneumonia. Am J Respir Crit Care Med 2013;187:1241-1248.

15. Singh S, Amin AV, Loke YK. Long-term use of inhaled corticosteroids and the risk of pneumonia in chronic obstructive pulmonary disease: a meta-analysis. Arch Intern Med 2009;169: 219-229.

16. Paggiaro PL, Dahle R, Bakran I, Frith L, Hollingworth K, Efthimiou $\mathrm{J}$. Multicentre randomised placebo-controlled trial of inhaled fluticasone propionate in patients with chronic obstructive pulmonary disease. International COPD Study Group. Lancet 1998;351:773-780.

17. Pauwels RA, Löfdahl CG, Laitinen LA, Schouten JP, Postma DS Pride NB, Ohlsson SV; European Respiratory Society Study on Chronic Obstructive Pulmonary Disease. Long-term treatment with inhaled budesonide in persons with mild chronic obstructive pulmonary disease who continue smoking. N Engl J Med 1999;340: 1948-1953.

18. Vestbo J, Sørensen T, Lange P, Brix A, Torre P, Viskum K. Long-term effect of inhaled budesonide in mild and moderate chronic obstructive pulmonary disease: a randomised controlled trial. Lancet 1999;353:1819-1823.

19. Crim C, Calverley PM, Anderson JA, Celli B, Ferguson GT, Jenkins C, Jones PW, Willits LR, Yates JC, Vestbo J. Pneumonia risk in COPD patients receiving inhaled corticosteroids alone or in combination: TORCH study results. Eur Respir J 2009;34: 641-647.

20. Kardos P, Wencker M, Glaab T, Vogelmeier C. Impact of salmeterol/ fluticasone propionate versus salmeterol on exacerbations in severe chronic obstructive pulmonary disease. Am J Respir Crit Care Med 2007;175:144-149.

21. Wouters EF, Postma DS, Fokkens B, Hop WC, Prins J, Kuipers AF, Pasma HR, Hensing CA, Creutzberg EC; COPD and Seretide: a Multi-Center Intervention and Characterization (COSMIC) Study Group. Withdrawal of fluticasone propionate from combined salmeterol/fluticasone treatment in patients with COPD causes immediate and sustained disease deterioration: a randomised controlled trial. Thorax 2005;60:480-487.

22. Rennard SI, Tashkin DP, McElhattan J, Goldman M, Ramachandran S, Martin UJ, Silkoff PE. Efficacy and tolerability of budesonide/ formoterol in one hydrofluoroalkane pressurized metered-dose inhaler in patients with chronic obstructive pulmonary disease: results from a 1-year randomized controlled clinical trial. Drugs 2009; 69:549-565.

23. Halpin DMG, Gray J, Edwards SJ, Morais J, Singh D. Budesonide/ formoterol vs. salmeterol/fluticasone in COPD: a systematic review and adjusted indirect comparison of pneumonia in randomised controlled trials. Int J Clin Pract 2011;65:764-774. 
24. Janson C, Larsson K, Lisspers KH, Ställberg B, Stratelis G, Goike H Jörgensen L, Johansson G. Pneumonia and pneumonia related mortality in patients with COPD treated with fixed combinations of inhaled corticosteroid and long acting $\beta 2$ agonist: observational matched cohort study (PATHOS). BMJ 2013;346:f3306.

25. Sin DD, Tashkin D, Zhang X, Radner F, Sjöbring U, Thorén A, Calverley PM, Rennard SI. Budesonide and the risk of pneumonia: a metaanalysis of individual patient data. Lancet 2009;374:712-719.

26. Boorsma M, Andersson N, Larsson P, Ullman A. Assessment of the relative systemic potency of inhaled fluticasone and budesonide. Eur Respir J 1996;9:1427-1432.

27. Thorsson L, Edsbäcker S, Källén A, Löfdahl CG. Pharmacokinetics and systemic activity of fluticasone via Diskus and pMDI, and of budesonide via Turbuhaler. Br J Clin Pharmacol 2001;52: 529-538.

28. Cheng SL, Wang HC, Cheng SJ, Yu CJ. Elevated placenta growth factor predicts pneumonia in patients with chronic obstructive pulmonary disease under inhaled corticosteroids therapy. BMC Pulm Med 2011;11:46.

29. Joo MJ, Au DH, Fitzgibbon ML, Lee TA. Inhaled corticosteroids and risk of pneumonia in newly diagnosed COPD. Respir Med 2010;104: 246-252.

30. Ko FWS, Ip M, Chan PKS, Ng SS, Chau SS, Hui DSC. A one-year prospective study of infectious etiology in patients hospitalized with acute exacerbations of COPD and concomitant pneumonia. Respir Med 2008;102:1109-1116.

31. Gershon AS, Campitelli MA, Croxford R, Stanbrook MB, To T, Upshur $R$, Stephenson AL, Stukel TA. Combination long-acting $\beta$-agonists and inhaled corticosteroids compared with long-acting $\beta$-agonists alone in older adults with chronic obstructive pulmonary disease. JAMA 2014;312:1114-1121.

32. Corren J, Korenblat PE, Miller CJ, O’Brien CD, Mezzanotte WS. Twelve-week, randomized, placebo-controlled, multicenter study of the efficacy and tolerability of budesonide and formoterol in one metered-dose inhaler compared with budesonide alone and formoterol alone in adolescents and adults with asthma. Clin Ther 2007;29:823-843.

33. Noonan M, Rosenwasser LJ, Martin P, O'Brien CD, O'Dowd L. Efficacy and safety of budesonide and formoterol in one pressurised metered-dose inhaler in adults and adolescents with moderate to severe asthma: a randomised clinical trial. Drugs 2006;66:2235-2254.

34. Sheffer AL, Silverman M, Woolcock AJ, Díaz PV, Lindberg B, Lindmark B. Long-term safety of once-daily budesonide in patients with earlyonset mild persistent asthma: results of the Inhaled Steroid Treatment as Regular Therapy in Early Asthma (START) study. Ann Allergy Asthma Immunol 2005;94:48-54.

35. Sibila O, Anzueto A, Restrepo MI. The paradoxical effect on pneumonia of chronic inhaled corticosteroids. Clin Pulm Med 2013;20:6-10.

36. Esmailpour N, Högger P, Rabe KF, Heitmann U, Nakashima M, Rohdewald P. Distribution of inhaled fluticasone propionate between human lung tissue and serum in vivo. Eur Respir J 1997;10: 1496-1499.

37. Barnes PJ. Corticosteroid effects on cell signalling. Eur Respir J 2006; 27:413-426.

38. McGaughey DS, Nikcevich DA, Long GD, Vredenburgh JJ, Rizzieri D, Smith CA, Broadwater G, Loftis JS, McDonald C, Morris AK, et al. Inhaled steroids as prophylaxis for delayed pulmonary toxicity syndrome in breast cancer patients undergoing high-dose chemotherapy and autologous stem cell transplantation. Biol Blood Marrow Transplant 2001;7:274-278.

39. Pieper M, Li G, Kashyap R, Thakur S, Ahmed A, Lee KM, Sharma P, Ivaskovic A, Cartin-Ceba R. Inhaled steroids - a protective factor for the development of acute lung injury in patients with pneumonia [abstract]. Crit Care Med 2009;37:A10.

40. Festic E, Ortiz-Diaz E, Lee A, Li G, Kor DJ, Adebola A, Akca O, Hoth J, Levitt JE, Carter R, et al.; United States Critical Illness and Injury Trials Group: Lung Injury Prevention Study (USCIITG-LIPS) Investigators. Prehospital use of inhaled steroids and incidence of acute lung injury among patients at risk. $J$ Crit Care 2013;28: 985-991.
41. Aaron SD, Vandemheen KL, Fergusson D, Maltais F, Bourbeau J, Goldstein R, Balter M, O'Donnell D, Mclvor A, Sharma S, et al.; Canadian Thoracic Society/Canadian Respiratory Clinical Research Consortium. Tiotropium in combination with placebo, salmeterol, or fluticasone-salmeterol for treatment of chronic obstructive pulmonary disease: a randomized trial. Ann Intern Med 2007;146: 545-555.

42. Burge PS, Calverley PMA, Jones PW, Spencer S, Anderson JA, Maslen TK. Randomised, double blind, placebo controlled study of fluticasone propionate in patients with moderate to severe chronic obstructive pulmonary disease: the ISOLDE trial. BMJ 2000;320: 1297-1303.

43. Calverley PM, Boonsawat W, Cseke Z, Zhong N, Peterson S, Olsson H. Maintenance therapy with budesonide and formoterol in chronic obstructive pulmonary disease. Eur Respir J 2003;22: 912-919.

44. Calverley P, Pauwels R, Vestbo J, Jones P, Pride N, Gulsvik A, Anderson J, Maden C; TRial of Inhaled STeroids ANd long-acting beta2 agonists study group. Combined salmeterol and fluticasone in the treatment of chronic obstructive pulmonary disease: a randomised controlled trial. Lancet 2003;361: 449-456.

45. Calverley PMA, Kuna P, Monsó E, Costantini M, Petruzzelli S, Sergio F, Varoli G, Papi A, Brusasco V. Beclomethasone/formoterol in the management of COPD: a randomised controlled trial. Respir Med 2010;104:1858-1868.

46. Doherty DE, Tashkin DP, Kerwin E, Knorr BA, Shekar T, Banerjee S, Staudinger $\mathrm{H}$. Effects of mometasone furoate/formoterol fumarate fixed-dose combination formulation on chronic obstructive pulmonary disease (COPD): results from a 52-week Phase III trial in subjects with moderate-to-very severe COPD. Int $J$ Chron Obstruct Pulmon Dis 2012;7:57-71.

47. Kerwin EM, Scott-Wilson C, Sanford L, Rennard S, Agusti A, Barnes N, Crim C. A randomised trial of fluticasone furoate/vilanterol $(50 / 25 \mu \mathrm{g}$ 100/25 $\mu \mathrm{g}$ ) on lung function in COPD. Respir Med 2013;107: 560-569.

48. Mahler DA, Wire P, Horstman D, Chang CN, Yates J, Fischer T, Shah T. Effectiveness of fluticasone propionate and salmeterol combination delivered via the Diskus device in the treatment of chronic obstructive pulmonary disease. Am J Respir Crit Care Med 2002; 166:1084-1091.

49. Martinez FJ, Boscia J, Feldman G, Scott-Wilson C, Kilbride S, Fabbri L, Crim C, Calverley PM. Fluticasone furoate/vilanterol (100/25; 200/25 $\mu \mathrm{g}$ ) improves lung function in COPD: a randomised trial. Respir Med 2013;107:550-559.

50. Szafranski W, Cukier A, Ramirez A, Menga G, Sansores R, Nahabedian $\mathrm{S}$, Peterson S, Olsson H. Efficacy and safety of budesonide/ formoterol in the management of chronic obstructive pulmonary disease. Eur Respir J 2003;21:74-81.

51. Tashkin DP, Rennard SI, Martin P, Ramachandran S, Martin UJ, Silkoff PE, Goldman M. Efficacy and safety of budesonide and formoterol in one pressurized metered-dose inhaler in patients with moderate to very severe chronic obstructive pulmonary disease: results of a 6-month randomized clinical trial. Drugs 2008;68:1975-2000.

52. Tashkin DP, Doherty DE, Kerwin E, Matiz-Bueno CE, Knorr B, Shekar T, Gates D, Staudinger H. Efficacy and safety characteristics of mometasone furoate/formoterol fumarate fixed-dose combination in subjects with moderate to very severe COPD: findings from pooled analysis of two randomized, 52-week placebo-controlled trials. Int J Chron Obstruct Pulmon Dis 2012;7:73-86.

53. van der Valk P, Monninkhof E, van der Palen J, Zielhuis G, van Herwaarden C. Effect of discontinuation of inhaled corticosteroids in patients with chronic obstructive pulmonary disease: the COPE study. Am J Respir Crit Care Med 2002;166: 1358-1363.

54. Vestbo J, Sørensen T, Lange P, Brix A, Torre P, Viskum K. Longterm effect of inhaled budesonide in mild and moderate chronic obstructive pulmonary disease: a randomised controlled trial. Lancet 1999;353:1819-1823. 
55. Vogelmeier CF, Bateman ED, Pallante J, Alagappan VKT, D'Andrea P, Chen H, Banerji D. Efficacy and safety of once-daily QVA149 compared with twice-daily salmeterol-fluticasone in patients with chronic obstructive pulmonary disease (ILLUMINATE): a randomised, double-blind, parallel group study. Lancet Respir Med 2013;1:51-60.

56. Welte T, Miravitlles M, Hernandez P, Eriksson G, Peterson S,

Polanowski T, Kessler R. Efficacy and tolerability of budesonide/ formoterol added to tiotropium in patients with chronic obstructive pulmonary disease. Am J Respir Crit Care Med 2009;180:741-750.
57. Joo MJ, Au DH, Fitzgibbon ML, Lee TA. Inhaled corticosteroids and risk of pneumonia in newly diagnosed COPD. Respir Med 2010;104: 246-252.

58. Festic E, Bansal V, Gajic O, Lee AS; United States Critical Illness and Injury Trials Group: Lung Injury Prevention Study Investigators (USCIITG-LIPS). Prehospital use of inhaled corticosteroids and point prevalence of pneumonia at the time of hospital admission: secondary analysis of a multicenter cohort study. Mayo Clin Proc 2014;89:154-162. 